DOI https://doi.org/10.30525/978-9934-26-180-0-36

\title{
СПОСОБИ ВІДТВОРЕННЯ ТАБУЙОВАНОЇ ЛЕКСИКИ У ТВОРІ МАРІО ВАРГАСА ЛЬОСИ «СКРОМНИЙ ГЕРОЙ»
}

\author{
Волинець Н. В. \\ аспірант кафедри іспанської та франиузької філології \\ Киӥвський національний університет \\ м. Київ, Украӥна
}

Сучасна іспаномовна художня література все частіше послуговується табуйованою, а за іншою термінологією ненормативною лексикою, адекватне відтворення якої іншою мовою $є$ одним із актуальних питань перекладознавчих студій. Ненормативна лексика формує достатньо великий пласт словника мови, до якого належать соціальні діалекти, а також стилістично знижена лексика (обсценна лексика, інвективи, вульгаризми, лайлива лексика та мат), проте до цих пір залишається відкритим питання систематизації, класифікації та комплексного вивчення різних за своєю природою табуйованих одиниць в перекладацькому аспекті.

Використання ненормативної лексики в художньому тексті є характерною рисою сучасної іспаномовної літератури. Твори всесвітньо відомого перуано-іспанського письменника Маріо Варгаса Льоси не $\epsilon$ виключенням. Роман «Скромний герой» побачив світ у 2013 році. Критики порівнюють цей твір автора 3 «Повчальними новелами» М. де Сервантеса, оскільки мова йде про історії, які часто поєднують іронію 3 нещастям, гумор із спустошенням [...], хитрощі досягнення щастя часто пов'язані

3 мужністю та розумом. Письменник грає з суперечливими почуттями і цінностями, гумором, ніжністю, ненавистю, любов'ю прощенням [1]. Завдяки вишуканому словесному мистецтву автора діалоги персонажів точні, досконалі, кожен має свій голос.

Однією із основних проблем при перекладі ненормативної лексики в художньому творі $є$ пошук тих відповідників, які б природньо відтворили таку лексику першотвору в культурі реципієнтів. Головне завдання перекладача при перекладі таких комунікативних одиниць, на думку мовознавця Д. Бузаджи зробити так, щоб нецензурна лексика виконувала ідентичну функцію, як і в тексті оригіналу. Вчений наголошує на тому, що лайливе слово не повинно втратити когнітивний компонент свого значення (якщо він важливий), а також переклад не повинен ані підсилювати, ані пом'якшувати його [2]. Ретельно вивчивши наукові 
дослідження, присвячені проблематиці відтворення ненормативної лексики, можемо виділити такі основні перекладацькі прийоми при перекладі іспаномовної лайливої лексики у творі М. Варгаса Льоси українською мовою: лексична заміна, вживання динамічного еквіваленту, дисфемістична заміна, калькування, перифраз, та прийом опущення.

Лексична заміна. У наведених прикладах перекладач застосовує лексичну заміну, тобто заміна лайки лексемою такої ж емоційної зарядки та семантичного спрямування, але іншого лексичного ряду тому що дослівний переклад (рита - повія, курва, лярва, стерво, сука; mierda-лайно, гівно; cabrón - козел, свиня, сволота) буде не зовсім доречним, оскільки підсилить/послабить смисл цих ненормативних одиниць та порушить прагматику висловлювання.

Este viejo de mierda se las sabe todas [3, p. 85].

Цьому клятому стариганю пальиі в рот не клади [4, с. 40].

Las putas nunca pagaban [3, p. 473].

Ці покидьки ніколи не платили [4, с. 194].

¿ Habrían maltratado esos cabrones a la amante de Felícito Yanaque? [3, p. 543].

Чи не позбиткувалися, бува, ці покидьки над коханкою Фелісіто Янаке? [4, с. 221].

Динамічний еквівалент. Застосування такого перекладацького прийому спрямоване на наближення емоційно-естетичної реакції читачів перекладу до реакції читачів оригіналу, але, як зазначає Ю. Найда, [5, с. 198-210] ідентичності в деталях при такому перекладацькому прийомі, бути не може. Завдяки такому прийому вдається зберегти та відтворити емоційне тло оригіналу. Розглянемо приклад:

...quiero decir que te has metido gran lío de puro ignorante...un lío de la puta madre [3, p. 418].

Мушу сказати, сам того не підозрюючи, ти здорово обкалявся... по самісінькі вуха [4, с. 172].

Por eso te podemos asegurar que te has metido en un grandísimo lío del carajo, tio [3, p. 417].

І можемо тебе запевнити, щуо ти по вуха в лайні, дядечку [4, с. 173].

Вживання дисфемізмів. При перекладі ненормативної лексики цей прийом дозволяє підсилити образливе, грубе та неприйнятне значення слова. Даний прийом є доречним, коли буквальний переклад або перифраза значно пом'якшують зміст висловлювання та можуть призвести до втрати емоційного забарвлення тексту. Наприклад:

Deja de hacerte pelotudo, que no te sienta nada [3, p. 414].

Не вдавай дупеля, тобі це не личить [4, с. 172]. 
Un cojudo, más bien. Un huevón a la vela, eso es lo que soy [3, p. 261].

Радше бовдуром. Таким собі довбаком на поготові [4, с. 105].

Viejo de mierda por aquí, que reviente cuanto antes por allá... [3, p. 83].

Клятий старий! Бодай він швидше здох! [4, p. 40].

Прийом калькування. Буквальний переклад виокремили французькі лінгвісти Ж. Дарбельне і Ж.-П.Віне [6]. Такий перекладацький прийом полягає у прямому перекладі слова або виразу мови-джерела мовою перекладу. Вчений В. Модестов зазначає, що буквальний переклад не завжди можливий, оскільки досить часто відсутній адекватний лексичний аналог у мові перекладу. Розглянемо декілька прикладів таких перекладацьких рішень [7, с. 242]. Наприклад:

Estira la pata esta misma noche, hermano [3, p. 85].

Старий відкине ноги иієї ночі, братику [4, с. 41].

Pobre hombre, ahora sí que esos conchas de su madre habían encontrado la manera de ablandarlo [3, p. 394].

Бідолашний, ияі сучі діти нарешті знайшли його вразливе місце [4, p. 164].

Перифраз. Цей прийом дозволяє передати думки автора схожими, але не точними виразами. Завдяки такому перекладацькому рішенню, перекладач зберіг та відтворив комунікативну функцію таких лексем. Наприклад:

El par de huevos mejor puestos que hay en Piura [3, p. 98].

Він найбільший сміливець у иілій П'юрі [4, с. 159].

¡Un matrimonio que además no vale un carajo! [3, p. 414].

До того ж ӥхній шлюб мідяка не вартий! [3, с. 172].

Jugaremos a la ruleta rusa y asi nos iremos de este mundo con huevos bien puestos, como el Seminario de tu apuesta [3, p. 440].

Зіграємо в російську рулетку й залишимо ией світ з набундюченими ясчками, як той Семінарист, з яким ти колись бився об заклад [4, с. 176].

Прийом опущення. Таке перекладацьке рішення застосовують коли а) певні лексеми не можливо адекватно відтворити; б) відповідно до мовних та стилістичних норм мови перекладу. Переважно, опущенню підлягають лексеми, які $є$ семантично надлишковими, і значення яких можна легко вилучити з контексту. Наприклад:

«Josefina es una hembrita de la pitri mitri» [3, p. 338].

Хосефіта - жіночка справна [4, с. 207].

Puta, que mal policía eres, Lituma.. [3, p. 577].

Який же з тебе кепський поліиай, Літумо... [4, с. 235].

Отже, опрацьований нами матеріал свідчить про те, що при перекладі ненормативної лексики іспаномовних художніх творів, перекладач 
застосовує різні прийоми, які спрямовані не тільки на відтворення предметного змісту твору, а й на збереження емоційного-естетичного забарвлення оригіналу, авторського стилю. До класу найпоширеніших, можна віднести лексичну заміну, перифразу, калькування, вживання дисфемізмів та динамічного еквівалента. Саме ці прийоми дають можливість перекладачеві якнайкраще передати смислові й комунікативні функції ненормативних лексичних одиниць, використаних автором твору.

\section{Література:}

1. Fernando R. Lafuente. «El héroe discreto» de Vargas Llosa: un culebrón cervantino. ABC Cultural. España, 2013. URL: https://www.abc.es/ cultura/cultural/20130909/abci-cultural-m104-libros-vargas201309091243.html (дата звернення 01.12.2021).

2. Бузаджи Д.М. Норма ненормативного6 ругаемся адекватно. Mocmbl. 2006. №1(9). C.43-45.

3. Vargas Llosa M. Héroe discreto. Paperback. 2013. 392 p.

4. Варгас Льоса М. Скромний герой: роман/ пер. 3 ісп. Харків, 2014. $479 \mathrm{c}$.

5. Eugene Nida. Toward a science of translation. Netherlands: Brill, 2003. 331p.

6. Ж.-П. Вине, Ж. Дарбельне. Технические способы перевода (Вопросы теории перевода в зарубежной лингвистике. Москва, 1978. C. $157-167$

7. Модестов В.С. Художественный перевод: история, теория, практика. Москва: издательство литературного института им. А.М. Горького, 2006. 463c. 